\title{
Development of Pre-Broken Sugar Cane Submitted to Treatments with Fertilizer and Vegetable Regulators
}

\author{
Tiago Gazola1*, Mário Luiz Cipola Filho², Paulo Otávio Risso³ \\ ${ }^{1}$ Universidade Estadual Paulista "Júlio de Mesquita filho"-UNESP_FCA, Botucatu, Brazil \\ ${ }^{2}$ Universidade de Marília, Marília, Brazil \\ ${ }^{3}$ Universidade do Sagrado Coração, Bauru, Brazil \\ Email: ^tiago-gazola@hotmail.com
}

How to cite this paper: Gazola, T., Filho, M.L.C. and Risso, P.O. (2018) Development of Pre-Broken Sugar Cane Submitted to Treatments with Fertilizer and Vegetable Regulators. Agricultural Sciences, 9, 1240-1249. https://doi.org/10.4236/as.2018.910087

Received: September 13, 2018

Accepted: October 22, 2018

Published: October 25, 2018

Copyright $\odot 2018$ by authors and Scientific Research Publishing Inc. This work is licensed under the Creative Commons Attribution International License (CC BY 4.0).

http://creativecommons.org/licenses/by/4.0/

\section{(c) (i) Open Access}

\begin{abstract}
The objective of this work was to evaluate the development of pre-budded sugarcane seedlings from buds submitted to treatments with fertilizer and plant regulators. The experiment was conducted in a completely randomized design with six replicates. The treatments of the yolks were carried out in the concentration of $1 \%$ of volume with the following products: Witness-without treatment of the gems; Kinetin 0.009\% + Gibberellic acid $0.005 \%+$ 4-Indole-3-butyric acid 0.005\% (Stimulate ${ }^{\circledR}$ ); Seaweed Extract (Ascophyllum nodosum) and Potassium Hydroxide- $3.5 \% \mathrm{~K}_{2} \mathrm{O}$ (ExpertGrow ${ }^{\circledR}$ ) and ethephon $72 \%\left(\right.$ Ethrel $\left.^{\circledR}\right)+\mathrm{pH}$ Reducer $\left(\mathrm{Kill}^{\mathbb{\circledR}}\right)$. The percentage of shoot buds, number of tillers, number of leaves, leaf area, stem diameter, shoot dry mass, root and total were evaluated. The control, as well as Stimulate ${ }^{\mathbb{R}}$ and Ethrel ${ }^{\mathbb{B}}$ provided higher sprouting percentages. Ethrel $^{\circledR}$ was the product that promoted the highest number of tillers and leaves. The leaf area did not change due to the use of the products or not. The dry mass of both shoot, root and total leaves showed no significant weight changes among the evaluated treatments. It is concluded that the use of ExpertGrow ${ }^{\circledR}$ is not recommended for treatment of pre-sprouted sugarcane seedlings because it provided fewer shoots at 28 days after planting of the yolk and that Ethrel ${ }^{\circledR}$ is recommended because it provided a larger number of the buds evaluated.
\end{abstract}

\section{Keywords}

Ascophyllum nodosum, Pre-Budded Seedlings, Plant Regulators, Saccharum spp. 


\section{Introduction}

Sugarcane (Saccharum officinarum L.) stands out in the Brazilian agribusiness with the production of sugar, ethanol and bioenergy, accounting for more than half of the sugar sold in the world. In the agricultural year of 2017/18, the area harvested in the country was $8.729,5$ thousand hectares, standing out the state of São Paulo, with about $52 \%$ of the area harvested, and the national production was 633.3 million tons [1].

However, the growth of the sugar and alcohol sector will only continue to advance in a sustainable manner if new seedling formation techniques are studied in order to favor agility in the process [2]. Among the methods used, the system of production of pre-budded seedlings (MPB) emerged as an excellent option for the resumption of nursery formation, since it allows reducing the time for the use of sugarcane, facilitates the adoption of new varieties with greater potential, ensures more uniform planting and provides greater plant health [3].

In addition, the system allows the reduction of the volume of stalks per hectare, the increase of the multiplication rate, the use of a smaller volume of material in the field and increase in the operability of the planting [4]. Conventional planting uses an average of 18 to 20 tons of stems per hectare, and in the MPB system this volume falls to 2 tons on average means that 18 tons of stalk per hectare can be used by industry to produce sugar and ethanol.

In this way, to form seedlings with quality is paramount, as it will directly influence the percentage of survival, speed and quality of growth and the final production of sugarcane, as well as to exercise better control of weeds and reduce the costs of cultural dealings [5]. One of the ways to improve the quality of these seedlings is to use fertilizer and plant regulators, as these products facilitate the entry of water into the cells, promote, inhibit or modify the physiology of plants and, consequently, will act on the internal morphological processes of the tissues of organisms which may respond positively to the application [6].

Several studies have been carried out to characterize the effect of plant regulators applied before or after emergence, or even in the budding and initial development of sugarcane, aiming at better tillering and final yield of stalks [7] [8] [9]. However, because it is a recent technology, the information found in the literature regarding the effects of the application of these products in MPB is scarce.

Given the facts, the hypothesis of the work was to verify if fertilizer and plant regulators can promote significant improvements in the biometric parameters of MPB. Thus, the objective of this work was to evaluate the development of pre-sprouted sugarcane seedlings from gemstones submitted to treatments with fertilizer and plant regulators.

\section{Materials and Methods}

The experiment was carried out in a protected environment, from September to November of 2017, in a seedling nursery in the municipality of Mineiros do 
Tietê, Brazil $\left(22^{\circ} 41^{\prime} 13^{\prime \prime S}\right.$ and $\left.48^{\circ} 45^{\prime} 59^{\prime \prime} \mathrm{W}\right)$. The design was completely randomized with six replicates.

For the formation of the seedlings, buds of the plant varieties RB036088 were extracted with an adapted plier from a second cut cane field of eight months and that was implanted in a production environment classified as " $A$ ". Afterwards, the treatments were applied, being: Witness—no treatment of the gems; Kinetin $0.009 \%+$ Gibberellic acid 0.005\% + 4-Indole-3-butyric acid 0.005\% (Stimulate ${ }^{\circledR}$ ); Extract of seaweed (Ascophyllum nodosum) and potassium hydroxide-3.5\%

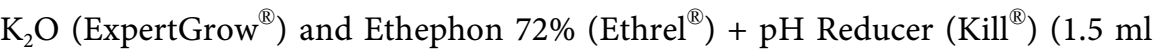
in $5 \mathrm{~L}$ of water). For this, the yolks were submerged for a period of 5 minutes in plastic containers containing 5 liters of water and $1 \%$ of the solution of the respective treatments.

Subsequently the yolks were planted in plastic trays of 30 cells with total capacity to $3.8 \mathrm{~L}$, duly filled with commercial substrate Carolina II that was previously homogenized with a mix of fertilizers. The substrate had the following physical/chemical characteristics: sphagnum peat; expanded vermiculite; peeled rice husk; dolomitic limestone; gypsum farming; traces of NPK; electrical conductivity $(\mathrm{EC})=0.7 \mathrm{mS} / \mathrm{cm} \pm 0.3 ; \mathrm{pH} 5.5$; density $155 \mathrm{~kg} \mathrm{~m}^{-3}$ and water holding capacity $55 \%$. he fertilizer mix was composed of $300 \mathrm{~g}$ of ammonium sulphate $(20 \% \mathrm{~N}$ and $22 \% \mathrm{~S})+200 \mathrm{~g} \mathrm{KCl}\left(60 \% \mathrm{~K}_{2} \mathrm{O}\right)+200 \mathrm{~g}$ thermophosphate $(18 \%$ $\mathrm{P}_{2} \mathrm{O}_{5}, 18 \% \mathrm{Ca}, 7 \% \mathrm{MgO}$ and $\left.10 \% \mathrm{Si}\right)+500 \mathrm{~g}$ of Basacote ${ }^{\circledR}$ Mini $3 \mathrm{M}(13 \% \mathrm{~N}, 6 \%$ $\mathrm{P}_{2} \mathrm{O}_{5}, 16 \% \mathrm{~K}_{2} \mathrm{O}, 1.4 \% \mathrm{MgO}, 10 \% \mathrm{~S}, 0.15 \% \mathrm{Fe}, 0.02 \% \mathrm{~B}, 0.02 \% \mathrm{Zn}, 0.05 \% \mathrm{Cu}$, $0.06 \% \mathrm{Mn}$ ) were added to each 100 liters of substrate.

The evaluations occurred at different times, being: percentage of plants that presented shoots at 14, 21 and 28 days after planting the gemstones (DAPG); and the other evaluations occurred at 56 DAPG in five central plants of each tray (repetition), where the analyzes of the number of tillers, stem diameter, number of leaves, leaf area, shoot dry mass, root dry mass and total dry mass. The stalk diameter was measured using a digital caliper (Western ${ }^{\circledR}$ PRO DC-6). The total leaf area of each plant $\left(\mathrm{cm}^{2}\right)$ was measured using a digital scanner (Area meter model LICOR-LI 3100C). The dry mass was obtained by drying the samples in a forced air circulation oven at $70^{\circ} \mathrm{C}$ to the constant mass.

The obtained data presented normal distribution and were submitted to analysis of variance by the $\mathrm{F}$ test and the means compared by the Tukey test at $\mathrm{p} \leq$ 0.05 . Correlation analysis was also performed to determine and establish the relationship between leaf area and leaf number.

\section{Results and Discussion}

The best production base of prefabricated seedlings (MPB) is the quality and viability of the plantations that are planted. One of the ways to measure is the analysis of a percentage of sprouting in the plant organs, so that the higher the percentage, the better the use of the plant material used [10]. It should be the main process for the sugarcane and explored commercial to one period average 
of the five years, and, also, all the stages are used for the canavial area, maintaining good productivity.

In this sense, it can be seen in Table 1 that the bud percentage of MPB buds showed a gradual increase in viability as a function of time. At 14 days after the planting of the gemstones (DAPG) Stimulate ${ }^{\circledR}$ was the product that promoted the best result with $66.66 \%$ buds sprouted, whereas the Ethrel ${ }^{\circledR}$ provided the lowest sprouting percentage with $16.66 \%$ (Table 1). At 21 DAPG, Stimulate ${ }^{\circledR}$ again was the treatment that showed the best bud budding, however, Ethrel $^{\circledR}$-treated buds showed increased viability with $70 \%$ sprouting (Table 1 ).

The cytokinin, a compound present in Stimulate ${ }^{\circledR}$, promotes several physiological changes in the plants, among them is the breakage of bud dormancy [11], which explains this better initial sprouting percentage in the buds treated with this product. The best sprouting percentage occurred at 28 DAPG and all products, except for ExpertGrow ${ }^{\circledR}$, had a percentage of sprouting above $80 \%$ (Table $1)$.

The use of ethephon in sugarcane planting systems provides an increase in the initial development of the crop in the budding stage [12]. However, gemstones that did not receive treatment with the products (control) also showed a high percentage of budding and did not differ statistically from Stimulate ${ }^{\circledR}$ and Ethrel $^{\circledR}$, demonstrating that the use of these plant regulators did not increase the final viability of the buds (Table 1 ).

Egarding the number of tillers, Ethrel ${ }^{\circledR}$ was the product that provided the highest amount of tillers at 56 DAPG in MPBs, differing statistically from the buds that were treated with Stimulate ${ }^{\circledR}$ and ExpertGrow ${ }^{\circledR}$ and from the control (Figure 1). The MPBs under the Ethrel ${ }^{\circledR}$ effect, averaged $75 \%$ more than the Stimulate $^{\circledR}$ treated gemstones, $94 \%$ more than the ExpertGrow ${ }^{\circledR}$ treated gemstones and $98.5 \%$ more than the control (Figure 1).

The budding process in the initial stage of the crop lasts approximately 21 days and is determinant in the formation of a profitable sugar cane, since it

Table 1. Percentage of sprouts in pre-sprouted sugarcane seedlings at 14, 21 and 28 days after planting of the gemstones.

\begin{tabular}{cccc}
\hline \multirow{2}{*}{ Treatments } & \multicolumn{3}{c}{ Days after planting of the gemstones (DAPG) } \\
\cline { 2 - 4 } & 14 DAPG & 21 DAPG & 28 DAPG \\
\hline Control & $46.66 \mathrm{~b}$ & $80.00 \mathrm{ab}$ & $85.55 \mathrm{a}$ \\
Stimulate & $66.66 \mathrm{a}$ & $82.22 \mathrm{a}$ & $86.66 \mathrm{a}$ \\
ExpertGrow & $47.77 \mathrm{~b}$ & $72.22 \mathrm{ab}$ & $77.77 \mathrm{~b}$ \\
Ethrel & $16.66 \mathrm{c}$ & $70.00 \mathrm{~b}$ & $83.33 \mathrm{a}$ \\
F & $216.25^{* *}$ & $4.80^{*}$ & $7.45^{* *}$ \\
C.V (\%) & 7.74 & 8.68 & 4.25 \\
\hline
\end{tabular}

$* *$, ${ }^{*}$ Significant at 1 and $5 \%$ probability, respectively, by the test of F. Means followed by the same letter, in the column did not differ significantly by Tukey test $(p \geq 0.05)$. 
guarantees the ideal population of plants in the field [13]. The action of ethephon in the treatment of sugarcane mini-reeds provides an increase of ethylene, promoting a decrease in the concentration of auxin due to the interruption of apical dominance, which starts to stimulate the tillering of the lateral gemstones of the shoots [14]. Moreover, when ethephon is applied in a plant with developed shoots, an increase in the number of tillers after harvesting occurs [9].

In order to guarantee a good production of stalks by cultivated area, tillering in the initial stage of sugarcane is a limiting factor to ensure an adequate tiller stand, in this way, a greater induction of tillering can provide greater productivity in a cane field [9], thus, Ethrel ${ }^{\circledR}$ contributes substantially to this process. Sugarcane tillering is limited, and for this reason, any cultural treatment that favors this process is of great benefit for the development of culture [15]. [16] In addition, that tillering begins around 40 days after planting and may last up to 120 days, and that currently about 1.5 to 2 tillers per yolk remain to form canes, a fact observed in this experiment with the use of $\mathrm{Ethrel}^{\circledR}$ (Figure 1).

Also described that tills when they are formed earlier help to produce thicker and heavier stalks [16]. However, when analyzing the stem diameter of sugarcane MPB, it can be seen that there was no significant difference between the treatments, showing that the products used did not exert an influence on this parameter evaluated, and that the increase of Tiller observed with Ethrel ${ }^{\circledR}$ (Figure 1) had no effect on stalk diameter (Figure 2). However, studied the effects of gibberellin and ethephon on the anatomy of sugarcane plants and observed the decrease of lignin in the stalks, favoring the accumulation of sugar in

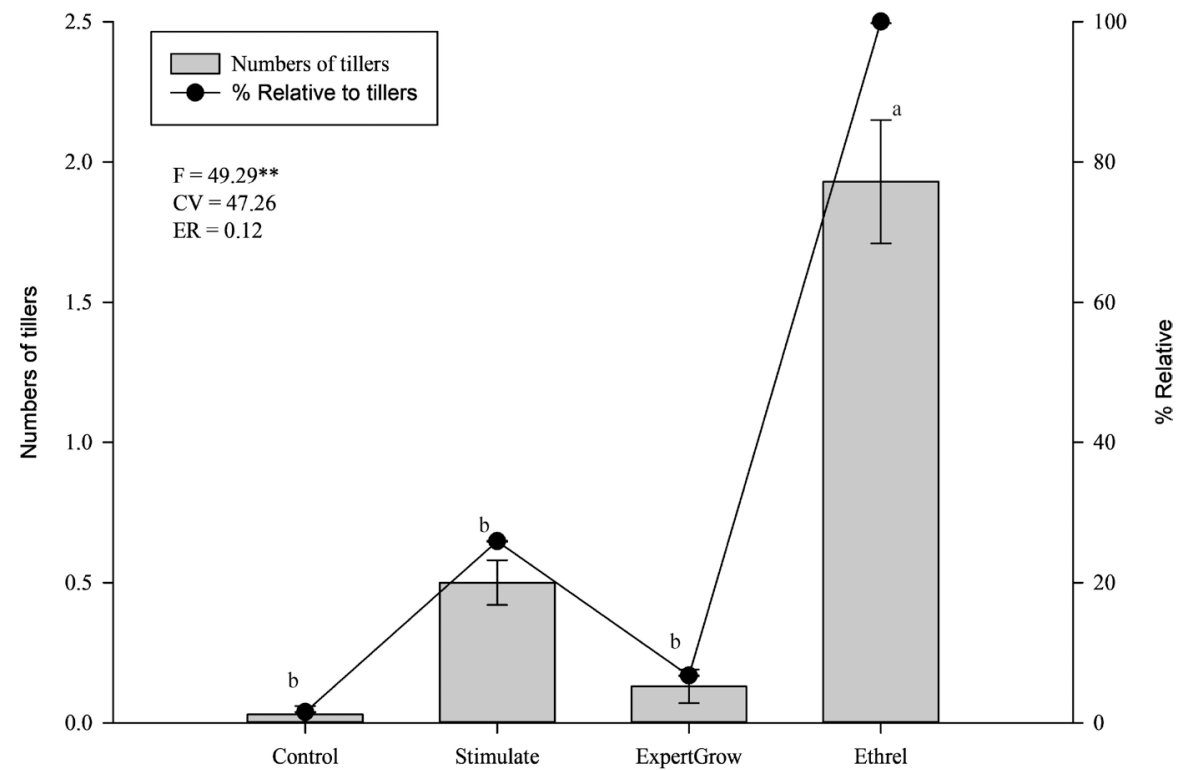

Figure 1. Number of tillers and percentage of tillers in pre-sprouted sugarcane seedlings at 56 days after planting of the buds (DAPG). Each column corresponds to the mean \pm standard error $(n=6) .{ }^{*}$ Significant at $1 \%$ probability by the test of F. ER standard error of the mean. CV coefficient of variation. Means followed by the same letter in the column do not differ significantly by the Tukey test $(\mathrm{p} \leq 0.05)$. 
the internal tissues [17]. Therefore, even if the stem diameter has not increased, the use of Ethrel ${ }^{\circledR}$ in the treatment of MPB has the potential to decrease lignin concentration in the stalks, but requires the need for further studies to prove this hypothesis.

In the evaluation of the photosynthetic apparatus, Ethrel ${ }^{\circledR}$ provided seedlings with greater number of leaves compared to other treatments (Table 2). On average, the Ethrel ${ }^{\circledR}$ treated buds produced seedlings with almost 2 times more leaves than the buds evaluated in the other treatments (Table 2). However, when analyzing the total leaf area of these seedlings in each treatment tested, it is possible to observe that there was no significant difference between them (Table 2).

The reason for this is that the Ethrel ${ }^{\circledR}$ provided leaves with smaller length and width, which explains the leaf area presenting a similar result to the other treatments.

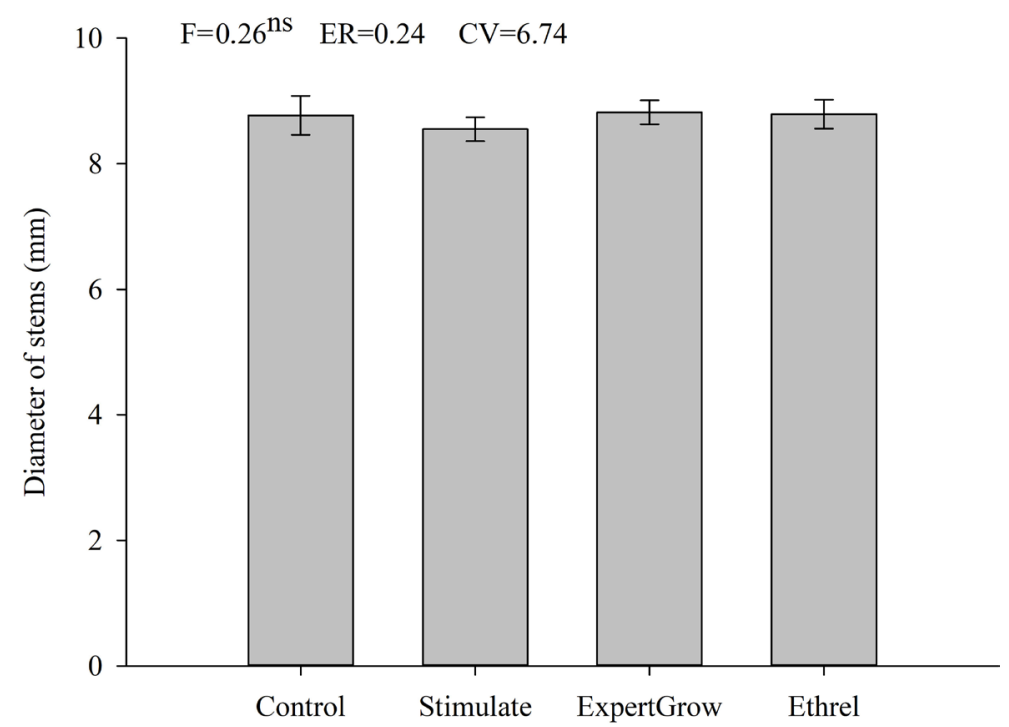

Figure 2. Diameter of stems in pre-sprouted sugarcane seedlings at 56 days after planting

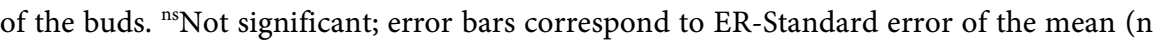
$=6)$. CV Coefficient of variation.

Table 2. Number of leaves and leaf area in pre-sprouted sugarcane seedlings at 56 days after planting of the gems.

\begin{tabular}{ccc}
\hline \multirow{2}{*}{ Treatments } & \multicolumn{2}{c}{56 Days after planting of the gems } \\
\cline { 2 - 3 } & Number of leaves & Leaf area $\left(\mathrm{cm}^{2}\right)$ \\
\hline Control & $8.10 \mathrm{~b}$ & 141.59 \\
Stimulate & $8.90 \mathrm{~b}$ & 141.03 \\
ExpertGrow & $8.23 \mathrm{~b}$ & 136.15 \\
Ethrel & $14.06 \mathrm{a}$ & 140.10 \\
F & $56.75^{* *}$ & $0.40^{\mathrm{ns}}$ \\
C.V $(\%)$ & 9.42 & 6.84 \\
\hline
\end{tabular}

ns, ${ }^{*}$ Not significant and Significant, respectively, at $1 \%$ probability by the test of F. Means followed by the same letter in the column do not differ significantly by the Tukey test $(p \geq 0.05)$. 
Note that there is no correlation between the increase in leaf number and the larger leaf area (Figure 3). In some situations, with the use of ExpertGrow ${ }^{\circledR}$, as the number of leaves in the plant increases, the leaf area is reduced, this is because the leaves produced are finer and shorter and the leaf area is not proportional to this increase (Figure 3(c)).

Leaf area responsible for light uptake in photosynthesis did not change as a function of the treatments tested, and this may explain why the stalk diameter did not differ between treatments. This may interfere in the establishment phase of the crop, as it occurs in the death and fall in the number of tillers, which causes a decrease in the number of shoots. This reduction in the number of tillers is directly linked to light, water and nutrient competition [8], which requires photosynthetically active leaves and a well developed root system present in the deepest layers of the soil.

In addition, as the leaf area is directly related to the higher photosynthetic rate in plants, it was expected that the dry matter mass of these seedlings presented similar results, since the final product of the photosynthesis is reflected in biomass.
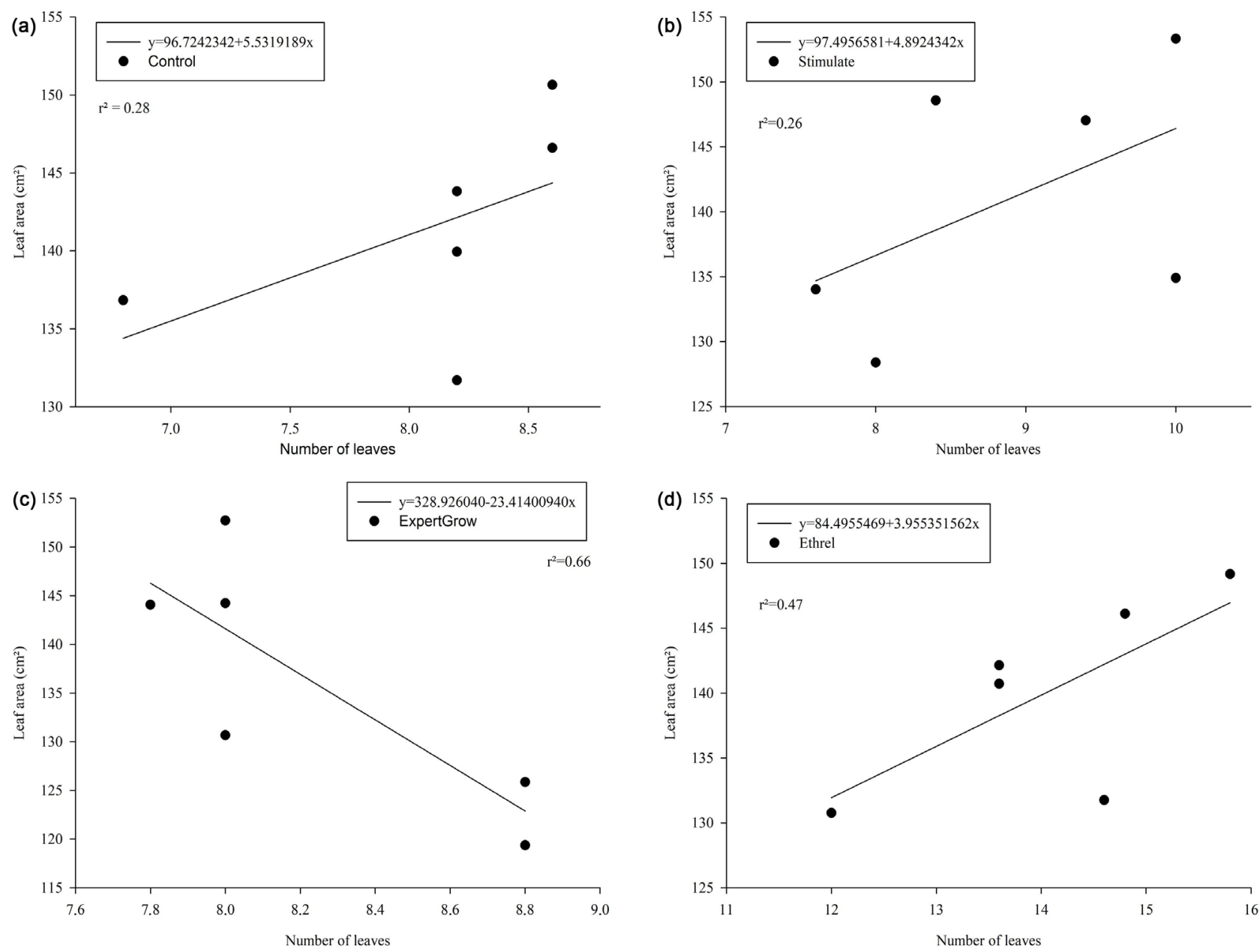

Figure 3. Correlation between the number of leaves and the leaf area in pre-sprouted sugarcane seedlings at 56 days after planting the buds (DAPG). 
Table 3. Mass of dry matter, shoot (MSPA), root (MSR) and total (MSTOTAL) in pre-sprouted sugarcane seedlings at 56 days after planting of the gemstones.

\begin{tabular}{cccc}
\hline \multirow{2}{*}{ Treatments } & \multicolumn{3}{c}{56 days after planting of the gemstones } \\
\cline { 2 - 4 } & MSPA & MSR & MSTOTAL \\
\hline Control & 2.12 & 0.72 & 2.84 \\
Stimulate & 2.04 & 0.91 & 2.95 \\
ExpertGrow & 2.12 & 0.80 & 2.92 \\
Ethrel & 1.97 & 0.95 & 2.92 \\
F & $1.43^{\text {ns }}$ & $1.46^{\text {ns }}$ & $0.12^{\text {ns }}$ \\
C.V $(\%)$ & 7.04 & 24.54 & 10.42 \\
\hline
\end{tabular}

${ }^{\mathrm{n}} \mathrm{Not}$ significant by $\mathrm{F}$ test.

The leaves are organs responsible for $90 \%$ of the dry mass accumulated in sugarcane, resulting from photosynthetic activity [18] [19].

It can be observed in Table 3 that the dry mass of the aerial part, root dry mass and total dry mass (aerial + root) of the MPBs at 56 DAPG did not show a significant difference, demonstrating the importance of the leaf area in the capture of light and efficiency photosynthetic by plants. Similar results were found in literature, when studying the effects of irrigation on MPB of sugarcane, it was observed that the mass of dry matter of roots ranged from 0.27 to $1.33 \mathrm{~g}$ at 76 days after planting and that the dry matter mass of the shoot varied between 1.40 and $2.80 \mathrm{~g}$ at 51 days after planting [20]. Values very close to those obtained in this experiment (Table 3 ).

The morphophysiology of plants depends not only on the presence of light, but also on attenuation and light quality [21], as well as the availability of nutrients present in the soil that influence the vegetative and reproductive development process [22] [19]. In studies involving foliar morphological alterations in sugarcane cultivars, they pointed out that some varieties were more resistant to water stress because they presented higher dry matter contents [23]. However, as observed in this experiment, no significant differences were observed in the dry matter of the seedlings evaluated (Table 3 ). In this sense, there were no benefits in the present research with the increase of the number of leaves observed with the use of Ethrel ${ }^{\circledR}$, since the leaf area was similar in all evaluated treatments.

\section{Conclusions}

ExpertGrow ${ }^{\circledR}$ is not indicated for the treatment of buds of pre-sprouted sugarcane seedlings because it provided a lower percentage of final sprouting and did not show benefits in the other evaluated parameters.

Ethrel $^{\circledR}$ is indicated for the treatment of MPB buds because the seedlings under their effect have a greater number of tillers, which is highly beneficial for the life and productivity of a sugar cane. 


\section{Conflicts of Interest}

The authors declare no conflicts of interest regarding the publication of this paper.

\section{References}

[1] CONAB-Companhia Nacional de Abastecimento (2018) Acompanhamento da Safra Brasileira-Cana-de-açúcar, quarto levantamento Safra 2017/18. Brasília, 4, $1-73$.

[2] Gazola, T., Cipola Filho, M.L. and Franco Júnior, N.C. (2017) Avaliação de mudas pré-brotadas de cana-de-açúcar provenientes de substratos submetidos a adubação química e orgânica. Científica Jaboticabal, 45, 300-306. http://dx.doi.org/10.15361/1984-5529.2017v45n3p300-306

[3] Anjos, I.A., Bidóia, M.A.P., Brancalião, S.R., Campana, M.P., Campos, M.F., Dinardo-Miranda, L.L., Figueiredo, P., Garcia, J.C., Kanthack, R.A.D., Landell, M.G.A., Mendonça, J.R., Miguel, P.E.M., Petri, R.H., Scarpari, M.S., Silva, D.N. and Xavier, M.A. (2013) Sistema de multiplicação de cana-de-açúcar com uso de mudas pré-brotadas (MPB), oriundas de gemas individualizadas. Instituto Agronômico, Campinas.

[4] Landell, M.G.A., Campana, M.P., Figueiredo, P., Xavier, M.A., Anjos, I.A., Dinardo Miranda, L.L., Scarpari, M.S., Garcia, J.C., Bidóia, M.A.P., Silva, D.N., Mendonça, J.R., Kanthack, R.A.D., Campos, M.F., Brancalião, S.R., Petri, R.H. and Miguel, P.E.M. (2012) Sistema de multiplicação de cana-de-açúcar com uso de mudas pré-brotadas (MPB), oriundas de gemas individualizadas. Instituto Agronômico de Campinas, Campinas, IAC Documentos 109.

[5] Morgado, I.F. (2000) Resíduos agroindustriais prensados como substrato para a produção de mudas de cana-de-açúcar. Scientia Agricola, 57, 709-712. https://doi.org/10.1590/S0103-90162000000400017

[6] Wekesa, R., Onguso, J.M., Nyende, B.A. and Wamocho, L.S. (2015) Sugarcane In Vitro Culture Technology: Applications for Kenya's Sugar Industry. Journal of Biology, Agriculture and Healthcare, 5, 127-134.

[7] Castro, P.R.C., Oliveira, D.A. and Panini, E.L. (1981) Ação do sulfometron metil como maturador da cana-de-açúcar. In: Castro, P.R.C., Sanguino, A. and Demétrio, C.G.B., Eds., Efeitos de reguladores vegetais no crescimento inicial da cana-de-açúcar, Brasil Açucareiro, Rio de Janeiro, 47-51.

[8] Castro, P.R.C. and Christoffoleti, P.J. (2005) Fisiologia da cana-de-açúcar. In: Mendonça, A.F., Ed., Cigarrinhas da cana-de-açúcar. Controle biologic, Insecta, Maceió, 3-48.

[9] Silva, M.A., Gava, G.J.C., Caputo, M.M., Pincelli, R.P., Jerônimo, E.M. and Cruz, J.C.S. (2007) Uso de reguladores de crescimento como potencializadores do perfilhamento e da produtividade em cana-soca. Bragantia, 66, 545-552. https://doi.org/10.1590/S0006-87052007000400003

[10] Quintela, A.C.R., Andrade, L.A.B., Carvalho, G.J. and Bocarbo, M.R. (1997) Efeito do plantio de cana inteira, com e sem desponte, e da compactação pós-colheita, em duas variedades de cana-de-açúcar. STAB Açúcar. Álcool e Subprodutos, 15, 22-24.

[11] Taiz, L. and Zeiger, E. (2004) Fisiologia Vegetal. Artmed, 3, 559 p.

[12] Jain, R., Solomon, S. and Chandra, A. (2011) Some Discernible Physio-Biochemical Chances Associated with Improved Sprouting of Sugarcane Setts Treated with 
Ethephon. Sugar Technology, New Dehli, 13, 123-128. https://doi.org/10.1007/s12355-011-0079-Z

[13] Aude, M.I.S. (1993) Estágios de desenvolvimento da cana-de-açúcar e suas relações com a produtividade. Ciência Rural, Santa Maria, 23, 241-248. https://doi.org/10.1590/S0103-84781993000200022

[14] Nailwal, T.K., Gupta, V.K., Sand, N.K. and Pant, R.C. (2004) Role of Ethylene in Tillering of Sugarcane (Saccharum officinarum L.). Physiology \& Molecular Biology of Plants, 10, 127-130.

[15] Silva, M.A., Carlin, S.D. and Perecin, D. (2004) Fatores que afetam a brotação inicial da cana-de-açúcar. Revista Ceres, 51, 457-466.

[16] Santos, F., Borém, A. and Caldas, C. (2010) Cana-de-açúcar. Bioenergia, açúcar e álcool: Tecnologias e perspectivas. Viçosa, [S.n.], $577 \mathrm{p}$.

[17] Martins, M.B.G. and Castro, P.R.C. (1999) Efeitos de giberelina e ethephon na anatomia de plantas de cana-de-açúcar. Pesquisa Agropecuária Brasileira, 34, 1855-1863. https://doi.org/10.1590/S0100-204X1999001000012

[18] Castro, P.R.C., Zambon, S., Sansígnolo, M.A., Beltrame, J.A. and Nogueira, M.C.S. (2002) Ação comparada de Ethrel, Fuzilade e Glifosato, em duas épocas de aplicação, na maturação e produtividade da cana-de-açúcar, variedade SP 70-1143. Revista de Agricultura, Piracicaba, 77, 23-38.

[19] Zhang, F., Zhang, K., Du, C., Li, J., Xing, Y., Yang, L. and Li, Y. (2015) Effect of Drought Stress on Anatomical Structure and Chloroplast Ultrastructure in Leaves of Sugarcane. Sugar Tech, 17, 41-48. https://doi.org/10.1007/s12355-014-0337-y

[20] Elia, P. (2016) Estabelecimento e desenvolvimento de mudas pré-brotadas de cana-de-açúcar sob diferentes lâminas de irrigação. Dissertação de mestrado (ciências engenharia de sistemas agrícolas). Escola superior de agricultura "Luiz de Queiroz", 88 p. https://doi.org/10.11606/D.11.2016.tde-09052016-180357

[21] Silva Júnior, J.M., Castro, E.M., Rodrigues, M., Pasqual, M. and Bertolucci, S. K.V. (2012) Variações anatômicas de Laelia purpurata var. cárnea cultivada in vitro sob diferentes intensidades e qualidade spectral de luz. Ciência Rural, 42, 480-486. https://doi.org/10.1590/S0103-84782012000300015

[22] Duru, M. and Ducrocq, H. (2000) Growth and Senescence of the Successive Leaves on a Cocksfoot Tiller. Ontogenic Development and Effect of Temperature. Annals of Botany, 85, 635-643. https://doi.org/10.1006/anbo.2000.1116

[23] Pincelli, R.P. and Silva, M.A. (2012) Alterações morfológicas foliares em cultivares de cana-de-açúcar em resposta à deficiência hídrica. Bioscience Journal, 28, 546-556. 